\title{
HIDROPISIA FETAL EM RECÉM-NASCIDO COM CITOMEGALIA CONGEENITA
}

Recém-nascido (RN) de parto cesárea, sexo feminino, branco, peso de nascimento de 920 gramas e Apgar $2 / 7 / 7$ nos $1^{\circ}$, $5^{\circ}$. e $10^{\circ}$. minutos de vida respectivamente. Mãe com 19 anos, primigesta, idade gestacional pela data da última menstruação de $27^{2 / 7}$ semanas, portadora de hepatite Be doença hipertensiva específica da gestação. Agravidez foi gemelar, tendo o primeiro gemelar nascido com hidropisia fetal grave indo a óbito com 20 horas de vida. 0 segundo gemelar foi classificado como prétermo de muito muito baixo peso (MMBP) e apresentava também ao nascimento hidropisia fetal acompanhada de derrame pericárdico. Foi encaminhado com uma hora de vida para a Unidade de Cuidados Intensivos Neonatal (UCINE) do Instituto da Criança-HCFMUSP. A admissão, o RN apresentava-se em mau estado geral, descorado $+++/ 4+$, taquicárdico, taquipnéico, fígado palpável a $4 \mathrm{~cm}$ do rebordo costal direito e baço a $2 \mathrm{~cm}$ do rebordo costal esquerdo, além de microcefalia. Inicialmente o RN recebeu concentrado de hemácias $(\mathrm{I} 5 \mathrm{ml} / \mathrm{Kg})$, plaquetas (I unidade), albumina ( $\mathrm{lg} /$ $\mathrm{Kg})$ e furosemida para sua estabilização hemodinâmica. Devido ao quadro clínico do paciente foi realizada pesquisa laboratorial para as infecções congênitas do grupo TORCHS (toxoplasmose, rubéola, citomegalovirus, herpes simples, sífilis, e hepatite vírus B e HIV). $O$ resultado foi negativo para todas estas infecções, exceto pela presença de anticorpos da classe IgG anticitomegalovírus que estavam presentes com título de I $48 \mathrm{UA} / \mathrm{ml}$ e anti-lgM negativo. A sorologia materna para CMV foi positiva com título de 195,20 UA/ml. Diante destes resultados laboratoriais, foi realizada no quinto dia de vida do RN a reação em cadeia da polimerase (PCR) na urina para o citomegalovírus tendosido positiva. Aultra-sonografia de crânio evidenciou a presença de pequenas imagens hiperecogênicas puntiformes talâmicas e periventriculares e a tomografia computadorizada demonstrou calcificações intracranianas esparsas. A pesquisa para parvovírus $B 19$ não foi possível de ser realizada. Devido ao quadro clínico sintomático e diagnóstico laboratorial de citomegalia congênita, foi introduzido durante sua evolução terapêutica com ganciclovir, na dose de $7,5 \mathrm{mg} / \mathrm{Kg} /$ dia, tendo recebido durante 14 dias. Após esse período foi iniciado esquema de manutenção, na dose de $10 \mathrm{mg} / \mathrm{Kg} /$ dia, três vezes por semana, o qual foi mantido durante 90 dias. Os exames de controle da PCR parao CMV realizados no sangue ena urina durante todo o tratamento com o ganciclovir permaneceram positivos, porém após três meses de tratamento com este fármaco, a PCR para CMV realizada no sangue do RN negativou, ou seja, não houve amplificação na amostra de DNAextraída do sangue periférico, não detectando a presença de CMV - DNA dentro dos leucócitos.

Durante sua permanência na UCINE, a criança evoluiu com persistência do canal arterial tendo realizado cirurgia corretiva. Desenvolveu ainda sepse e displasia broncopulmonar complicada com hipertensão pulmonar, necessitando de ventilação mecânica por tempo prolongado, vindo a receber alta com nove meses de idade, estando no momento em acompanhamento clínico.

A infecção intra-uterina pelo CMV é uma das mais freqüentes infecções congênitas de transmissão transplacentária hematogênica. Sua incidência varia de $0,2 \%$ a $2,4 \%$ de todos os nascidos vivos sendo a grande maioria das crianças assintomática ao nascimento. Cerca de $5 \%$ ou menos dos RN infectados apresentam a doença na sua forma sintomática com comprometimento generalizado, principalmente neurológico (microcefalia, hidrocefalia com calcificações intracranianas) ocular (coriorretinite) e auditivo (surdez sensorioneural), além de manifestações clínicas viscerais cujos sinais e sintomas clínicos mais freqüentes são: retardo de crescimento intra-uterino, anemia, trombocitopenia, hepato-esplenomegalia icterícia colestática e mais raramente hidropisia fetal, a qual pode estar presente em outras condições patológicas, como doenças cardíacas congênitas, doença adenomatoide cística pulmonar e infecções intra-uterinas como sífilis, doença de Chagas, infecção pelo Parvovirus B 19. A detecção de ácido nucléico viral pela reação da Polimerase (amplificação do DNA viral) em várias amostras de urina da paciente nos permitiu definir o diagnóstico de citomegalia congênita. Embora não tenha sido possível saber a causa de óbito do primeiro gemelar que era hidrópico, apresentamos o segundo gemelar que apesar da gravidade da infecção congênita pelo CMV, e da prematuridade extrema com várias complicações clínicas, sobreviveu estando em acompanhamento clínico. Acreditamos que a evolução favorável da infecção pelo CMV do paciente possa também estar relacionada ao tratamento prolongado com ganciclovir, medicamento que tem sido utilizado para o tratamento da infecção congênita sintomática pelo CMV.

\section{Flávio Adolfo Costa Vaz}

Edna M. Albuquerque Diniz

Trabalho realizado na Unidade de Cuidados Intensivos Neonatal do Instituto da Criança Hospital das Clínicas da Faculdade de Medicina da USP - São Paulo - SP 